\begin{tabular}{|l|l|l|l|l|l|}
\hline J. Tek. Ling & Vol. 13 & No. 2 & Hal. 159 - 166 & Jakarta, Mei 2012 & ISSN 1441-318X \\
\hline
\end{tabular}

\title{
UNJUK KERJA PENGOLAHAN LIMBAH CAIR TAHU SECARA BIOLOGI
}

\author{
Indriyati dan Joko Prayitno Susanto \\ Peneliti di Pusat Pengkajian Pengkajian dan Penerapan Teknologi Lingkungan \\ Badan pengkajian dan Penerapan Teknologi, Jakarta
}

\begin{abstract}
Abstrak
Sebagian besar industri makanan, termasuk industri tahu membuang limbah cairnya yang mengandung bahan organik dengan kadar tinggi (lebih dari 16,483 mg/L) langsung ke badan air. Dengan menggunakan teknologi yang tepat, limbah cair ini dapat diolah lebih lanjut untuk menghasilkan produk samping berupa biogas yang mengandung gas methan sebagai substitusi energi pada industri yang bersangkutan. Desa Kalisari merupakan salah satu sentra industri UKM tahu, untuk mengolah limbah cair yang dihasilkan oleh industri-industri ini diperlukan reaktor biogas "anaerobic digester " dengan kapasitas $20 \mathrm{~m}^{3}$. Hasil pengolahan limbah cair ini, disamping dapat menurunkan kandungan bahan organik yang terkandung, juga sekaligus dapat menghasilkan biogas yang produksinya sangat tergantung pada laju beban (loading rate) yang dimasukkan ke dalam reaktor. Tujuan penelitian ini adalah untuk memperoleh laju beban dan produksi biogas yang optimal sebagai dasar untuk mengetahui unjuk kerja optimal (optimum performance) Fixed Bed reactor untuk mengolah limbah cair tahu dari 25 industri tahu rumah tangga.
\end{abstract}

Kata kunci : anarobic, Fixed Bed.

\begin{abstract}
Almost of food industries such as tofu industry discharge waste water that high organic content in about $16,483 \mathrm{mg} / \mathrm{L}$ and the application method of waste water treatment produce side product such as biogas that contain methane gas, that biogas can used as energy substitution for the industry itself. According to the experienced in the Kalisari village there are a lot of small scale tofu industries, and it was built a $20 \mathrm{~m}^{3}$ bio reactor to treat the waste water. The tofu industry waste water is treated anaerobic by using anaerobic digester. Beside, reducing the organic pollutant, it is also produce biogas depend on the organic loading rate which come to the reactor. In this experiment are to find out the optimum of loading rate and also looking for the optimum gas production. According to organic loading rate can be seen the optimum performance of Fixed Bed reactor. The optimum biogas production is used to run the stoves for 25 households.
\end{abstract}

Key word : anarobic, Fixed Bed. 


\section{PENDAHULUAN.}

\subsection{LatarBelakang}

Perkembangan industri dewasa ini telah memberikan sumbangan besar terhadap perekonomian Indonesia. Di lain pihak perkembangan ini juga telah memberikan dampak lain terhadap kelangsungan lingkungan hidup yaitu berupa pencemaran lingkungan sebagai akibat buangan industri yang tidak memenuhi standard baku mutu yang telah ditetapkan. Industri tahu adalah salah satu industry skala kecil dan menengah yang juga mengalami perkembangan cukup pesat. Saat ini di Indonesia terdapat 84,000 unit industry tahu dengan kapasitas produksi lebih dari 2,56 juta ton per tahun yang tersebar di seluruh Indonesia terutama di Pulau Jawa.

Permasalahan yang timbul adalah perkembang industri tahu tersebut tidak diiringi dengan kesadaran lingkungan yang memadai. Industri tahu pada umumnya merupakan industry rumah tangga yang membuang hasil limbahnya secara langsung kelingkungan tanpa didahului dengan pengolahan, sehingga sangat berpotensi menimbulkan pencemaran. Limbah industry tahu ini dapat berupa limbah padat dan cair, tetapi limbah cair memiliki tingkat pencemaran lebih besar dari pada limbah padat.

Karakteristik limbah cair industry tahu meliputi dua hal, yaitu karakteristik fisika dan kimia. Karakteristik Fisika meliputi padatan total, padatan tersuspensi, suhu, warna, dan bau. Karakteristik kimia meliputi bahan organik, bahan anorganik dan gas.

Dari laporan hasil penelitian, terungkap bahwa kandungan rata-rata bahan pencemar dalam limbah cair tahu dari salah satu industri tahu di Surabaya adalah BOD : 5389,5 mg/l, COD : $7050 \mathrm{mg} / \mathrm{l}, \mathrm{N}$ Total : 161,5 $\mathrm{mg} / \mathrm{l}, \mathrm{P}$ Total : 81,6 gram/l dan $\mathrm{pH} 4,11^{1}$. Secara nasional, kandungan rata-rata bahan pencemar ini adalah BOD, COD dan TSS berturut-turut sebesar 3250 mg/liter, 6520 $\mathrm{mg} /$ liter dan $1500 \mathrm{mg} / \mathrm{lt}^{2}{ }^{2}$

Jika dibandingkan dengan nilai ambang batas yang diperbolehkan dalam peraturan KEP-51/MENKLH/10/1995 untuk baku mutu limbah cair bagi kegiatan industri ${ }^{3)}$, yaitu $\mathrm{BOD}_{5}$ : $50 \mathrm{mg} / \mathrm{l}, \mathrm{COD}: 100 \mathrm{mg} / \mathrm{l}$, TSS: $200 \mathrm{mg} / \mathrm{l}$ dapat dilihat dengan sangat jelas bahwa limbah cair tahu telah melewati batas ambang yang diperbolehkan. Untuk dapat memenuhi baku mutu yang dipersyaratkan, limbah cair tahu harus diolah dengan menggunakan teknologi yang tepat. Teknologi yang digunakan dapat dilakukan dalam proses dengan menggunakan prinsip in pipe, yakni dengan peningkatan efisiensi proses produksi sehingga limbah yang keluar dapat dikurangi kandungan organiknya sejak awal. Teknologi dengan prinsip end pipe juga diperlukan dalam mengolah limbah supaya memenuhi baku mutu atau bahkan digunakan kembali menjadi produk yang lain (Waste to Product) misalnya energy atau dikenal dengan istilah waste to energy.

Teknologi yang saat ini kianberkembang, telah memungkinkan limbah cair tahu untuk dapat diproses kembali menjadi energi yang dapat digunakan untuk menggantikan bahan bakar dalam memenuhi kebutuhan energiharian masyarakat.

Dalam penelitian ini, penulis ingin mengkaji lebih mendalam unjuk kerja Anaerobic Fixed bed Reactor dalam mengolaan limbah cair industry tahu dalam upaya menurunkan kandungan polutan agar dapat memenuhi baku mutu yang telah ditetapkan.

Penelitiaan ini dilaksanakan di Desa Kalisari yang merupakan salah satu desa yang termasuk kedalam wilayah Kecamatan Cilongok Kabupaten Banyumas. Desa ini merupakan desa sentra industry tahu, yang pada tahun 2007 terdapat 312 industri tahu skala kecil dengan total kapasitas produksi 7,5 ton per hari ${ }^{4}$. Berkembangnya industri tahu di wilayah ini, disamping telah menjadi motor penggerak ekonomi desa, disisi lain telah menimbulkan permasalahan lingkungan yang serius akibat dari pembuangan 
limbah cair tahu ke lingkungan sehingga menimbulkan masalah bau, penurunan kualitas air dan tanah, penurunan kualitas produk pertanian.

Penggunaan teknologi anaerobik dengan menggunakan reaktor rektor fixed bed (reaktor unggun tetap), selain dapat membantu menyelesaikan permasalahan pencemaran lingkungan akibat limbah cair tahu, juga dapat membantu masyarakat dalam perolehan energi yang dapat digunakan untuk kegiatan harian, sehingga membantu menyelesaikan masalah krisis energi yang dihadapi bangsa ini karena biogas merupakan salah satu energi alternatif yang ramah lingkungan yang bisa menggantikan LPG yang keberadaannya makin terbatas karena berasal dari fosil. Selain itu, diharapkan bahwa penggunaan biogas dari pengolahan limbah cair tahu dapat menjadi basis dalam pengembangan sentra industri tahu menjadi desa mandiri energi.

\subsection{Tinjauan Pustaka}

Penerapan teknologi pengolahan limbah secara biologi merupakan salah satu metode untuk mengolah limbah cair yang berasal dari indistri makanan, termasuk industri tahu. Penerapan metode ini sangat tergantung pada kualitas air baku dan kondisi fasilitas yang tersedia ${ }^{4)}$

Pengolahan limbah cair yang mengandung bahan organik secara biologi pada umumnya dilakukan dengan memanfaatkan aktivitas mikroorganisme yang dikondisikan secara terkontrol. Salah satu cara pengolahan limbah cair ini adalah menggunakan sistem reaktor anaerobik lekat terendam dengan media penyangga tetap (Anaerobic Fixed Bed Reactor).

Reaktor anaerobik dengan media penyangga tetap diperkenalkan pertama kali pada tahun $1987^{5}$ ) Bioreaktor ini adalah reaktor yang terdiri dari tangki berisi bahan pembantu berupa material penyangga tetap atau media. Fungsi dari material penyangga/ media ini adalah sebagai tempat menempel atau rumah mikroorganisme, sehingga mikroorganisme tidak ikut terbawa cairan sisa buangan atau effluen yang keluar dari reaktor.

Proses yang terjadi pada reaktor anaerobik tipe Fixed Bed adalah: air buangan yang akan diolah dialirkan ke dalam reaktor melewati media. Pada reaktor ini dicapai waktu tinggal yang pendek dan beban organik yang tinggi, akibat pertumbuhan biofilm pada permukaan media. Tidak semua bakteri melekat pada media. Bakteri yang melekat pada media berada pada ruangruang diantara media sehingga kecepatan aliran harus dijaga agar tidak terlalu cepat karena akan mengakibatkan bakteri-bakteri tersebut terlepas dari media dan terbawa keluar.

Proses anaerob adalah pengolahan biologi yang memanfaatkan mikroorganisme dalam mendegradasi bahan organik dalam kondisi tidak didapatkan atau sangat sedikit oksigen terlarut. Keuntungan dan kerugian pengolahan anaerob ${ }^{6}$ adalah dalam prosesnya menghasilkan energi dalam bentuk biogas, lumpur yang dihasilkan sedikit, tidak memerlukan lahan yang besar dan tidak membutuhkan energi untuk aerasi.

Kekurangan yang utama pada sistem anaerobik adalah proses pertumbuhan mikroorganismenya lambat yang mempunyai waktu pertumbuhan dalam hitungan hari bila dibandingkan dengan mikroorganisme yang tumbuh pada proses aerob ${ }^{7}$.

Dalam Anaerobic Fixed Bed Reactor, material penyangga tetap berfungsi sebagai tempat menempel atau rumah mikroorganisme agar tidak ikut terbawa cairan sisa buangan atau effluen yang keluar dari reaktor. Material penyangga tetap dapat dibuat dari berbagai macam bahan tidak terdegradasi, misalnya: plastik, keramik, tanah liat, batu apung atau bahan alam lainnya. Ukuran dan bentuk material penyangga tetap yang digunakan dapat berbentuk tidak beraturan, yang dibuat dari sejenis plastik dengan bentuk geometri 
tertentu dan potongan bambu dengan ukuran tertentu.

Material penyangga tetap dalam bioreaktor dapat berfungsi memperbanyak jumlah bakteri didalam reaktor ${ }^{8}$.

Tabel 1. Karakteristik Beberapa Macam Penyangga/Media.

\begin{tabular}{|l|c|c|}
\hline \multicolumn{1}{|c|}{ Jenis } & $\begin{array}{c}\text { Luas } \\
\text { Permukaan } \\
(\mathrm{m} 2 / \mathrm{m3})\end{array}$ & Porositas (\%) \\
\hline Kerikil & $>50$ & 50 \\
\hline Bambu & 81 & 75 \\
\hline Leca & 400 & 40 \\
\hline Hilow-rings & 65 & 97 \\
\hline Pall-ring & 102 & 95 \\
\hline Flocor R & 320 & 97 \\
\hline Clay Block & 140 & 55 \\
\hline Plasdek C-10 & 148 & 96 \\
\hline
\end{tabular}

Dari beberapa laporan hasil penelitian mengungkapkan bahwa, secara umum limbah cair organik dengan konsentrasi tinggi dapat diolah menggunakan reaktor "Anaerobic Fixed Bed Reactor" dengan capaian hasil yang sangat optimal. ${ }^{9,10,11)}$

\subsection{Tujuan}

Tujuan penelitian ini adalah untuk memperoleh loading rate dan produksi biogas yang optimal sebagai dasar untuk mengetahui unjuk kerja optimal (optimum performance) Fixed Bed reactor untuk mengolah limbah cair tahu dari 25 industri tahu rumah tangga.

\section{METODOLOGI}

\subsection{Lokasi}

Penelitiaan ini dilaksanakan di Desa Kalisari yang merupakan sentra industry tahu yang masuk dalam wilayah administrasi Kecamatan Cilongok, Kabupaten Banyumas, Provinsi Jawa Tengah.

\subsection{Pengolahan Limbah Cair Tahu.}

Dalam penelitian ini digunakan reactor anaerobic tipe Fixed bed yang berisikan material penyangga berupa potongan bamboo tempat bakteri menempel berukuran $20 \mathrm{~m}^{3}$. Limbah cair dari 50 rumah industry tahu yang terdapat disekitar tempat pengolahan limbah dialirkan menuju tangki penampung berukuran $6 \mathrm{~m}^{3}$ menggunakan pipa PVC yang kemudian dipompakan menuju reactor anaerobic secara upflow yaitu cairan limbah tahu dimasukan daribagian bawah kemudian terdistribusi di antara material penyangga tetap dan keluar melalui bagian atas ${ }^{12)}$.

Untuk mencapai hasil yang optimum, umpan yang dimasukkan secara bertahap dengan laju beban organik yang dipompakan kedalam reactor secara periodik, yaitu masing-masing : $0,40 \mathrm{Kg} / \mathrm{m}^{3} \mathrm{COD}$ total, $1,08 \mathrm{Kg} / \mathrm{m}^{3} \mathrm{COD}$ total, $2,40 \mathrm{Kg} / \mathrm{m}^{3} \mathrm{COD}$ total, $3,02 \mathrm{Kg} / \mathrm{m}^{3} \mathrm{COD}$ total dan $3,22 \mathrm{Kg} / \mathrm{m}^{3} \mathrm{COD}$ total.

Dalam penelitian ini dilakukan pengamatan harian terhadap parameter parameter : produksi gas, $\mathrm{pH}$, kadar methan, dan pengamatan setiap 2 (dua) kali dalam seminggu terhadap parameter parameter :COD inlet dan outlet, Total suspended solid (TSS).

\subsection{Peralatan/alatukur}

Dalam penelitian ini, peralatan utamayang digunakan adalah : Satu unit reaktor tipe fixed bed atau reaktor lekat diam terendam, pH meter, Gas Meter, Spektrophotometer dan Oven

\section{HASIL DAN PEMBAHASAN}

Dalam penelitian ini, laju beban reaktor diberikan kepada reaktor dengan cara pemberian umpan substrat yang semakin meningkat. Pada setiap kenaikan laju beban dilakukan dengan cara menambahkan umpan substrat untuk memperoleh kestabilan reaktor (steady state). Kestabilan reaktor 
ditunjukkan oleh konsentrasi COD efluen yang konstan, atau efisiensi yang relatif tetap, serta kandungan gas metana yang tetap, $\mathrm{pH}$ yang tetap netral sekitar $6-7$. Untuk proses optimalisasi dalam penelitian ini dilakukan selama 5 (lima) periode waktu dengan hasil yang dapat dilihat pada tabel 1.

Dari hasil pengamatan data ini, sebagaimana ditunjukkan pada Gambar 3.1. dapat disampaikan bahwa besarnya umpan yang diberikan berpengaruh terhadap kenaikan produksi harian biogas dan gas metana. Semakin besar umpan substrat yang diberikan ke dalam reaktor, produksi biogas harian semakin meningkat. Proses anaerobik masih berjalan dengan baik belum mencapai kondisi maksimal, bila bahan organik dapat didegradasi oleh mikroba sampai menjadi gas metana dengan mengikuti jalur degradasi bahan organik.

Semakin meningkatnya umpan substrat yang diberikan berpengaruh pula terhadap konsentrasi COD total dan COD terlarut pada efluen. Demikian pula keadaan kandungan gas metana yang pada awalnya cukup tinggi dan masih terlihat cukup tinggi walaupun jumlah substrat yang diberikan sudah

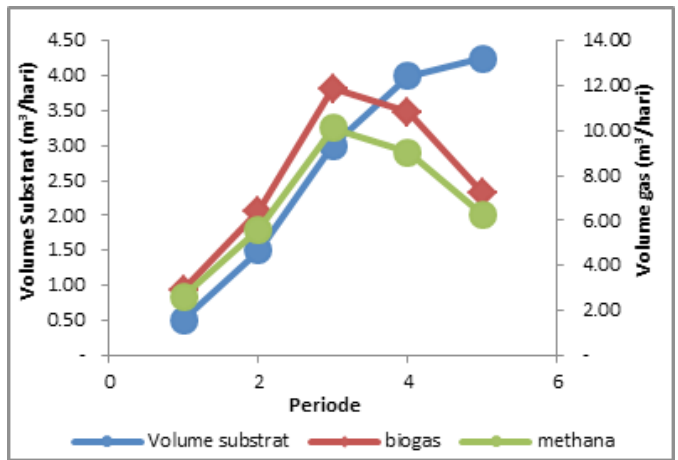

Gambar 3.1. Pengaruh volume substrat terhadap produksi biogas dan metana

mendekati desain reaktor sekitar 5 hari. Kandungan gas metana yang dihasilkan masih mendekati degradasi bahan organik dengan komponen utama yang berasal dari protein sebesar $70 \%$ (gambar 3.2).

Hasil penelitian ini dapat diterangkan bahwa degradasi senyawa anaerobik menjadi metana sesuai dengan stoikiometri reaksi yang terjadi, dimana pemecahan zat organik secara langsung mempunyai korelasi langsung dengan jumlah produksi metana. Secara teoritis, dari $1 \mathrm{~kg}$ COD yang terdegradasi, dapat terbentuk metana

Tabel 1. Hasil pengamatan pada prosesoptimalisasi digester.

\begin{tabular}{|l|l|r|r|r|r|r|}
\hline \multirow{2}{*}{ NO } & \multicolumn{2}{|c|}{ PARAMETER } & \multicolumn{6}{c|}{ HASIL SETIAP PERIODE } \\
\cline { 3 - 7 } & & $\mathbf{1}$ & $\mathbf{2}$ & $\mathbf{3}$ & $\mathbf{4}$ & $\mathbf{5}$ \\
\hline 1. & Volume substrat (m3/hari) & 0,5 & 1,5 & 3,0 & 4,0 & 4,25 \\
\hline 2. & Laju beban (kgCOD/m3.hari) & 0,40 & 1,08 & 2,40 & 3.02 & 3.22 \\
\hline 3. & COD total influen (mg/L) & 16.122 & 15.062 & 16.821 & 15.825 & 15.950 \\
\hline 4. & COD total efluen (mg/L) & 3.492 & 2.088 & 2.128 & 3.798 & 3.900 \\
\hline 5. & pH influen & 3,90 & 3,83 & 5,02 & 4,97 & 4,02 \\
\hline 6. & pH efluen & 6,29 & 6,08 & 6,88 & 7,10 & 7,28 \\
\hline 7. & Biogas (m3/hari) & 2,895 & 6,42 & 11,86 & 10,83 & 7,26 \\
\hline 8. & Kandungan metana (\%) & 90 & 87,3 & 85,3 & 83,3 & 86,6 \\
\hline 9. & Gas metana (m/hari) & 2,61 & 5,60 & 10,12 & 9,02 & 6,28 \\
\hline 10. & Efisiensi COD total (\%) & 78,34 & 86,13 & 87,35 & 76 & 75,54 \\
\hline 11. & Total suspended solid influen(mg/L) & 930 & 548 & 738 & 640 & 610 \\
\hline 12. & Total suspended solid efluen(mg/L) & 706 & 450 & 547 & 558 & 575 \\
\hline 13. & Total suspended solid didalam & 224 & 98 & 191 & 82 & 35 \\
\hline
\end{tabular}




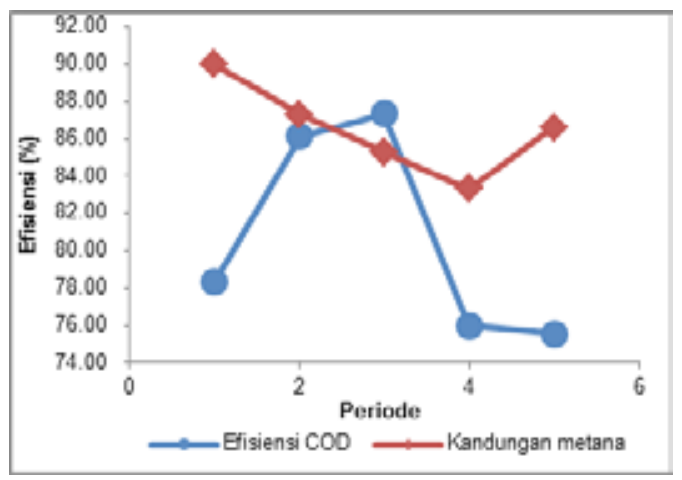

Gambar 3.2. Pengaruh volume terhadap Efisiensi COD total dan kandungan metana (\%)

sebanyak 350 liter. Buswell dan Mueller ${ }^{(13)}$ telah mengembangkan persamaan untuk menghitung produksi metana dan $\mathrm{CO}_{2}$ dalam biogas dari penentuan komposisi kimia limbah yang terdegradasi :

$$
\begin{aligned}
& \mathrm{C}_{n} \mathrm{H}_{\mathrm{a}} \mathrm{O}_{\mathrm{b}}+(\mathrm{n}-\mathrm{a} / \mathrm{b}-\mathrm{b} / 2) \mathrm{H}_{2} \mathrm{O} \rightarrow \\
& (\mathrm{n} / 2-\mathrm{a} / 8+\mathrm{b} / 4) \mathrm{CO}_{2}+(\mathrm{n} / 2+\mathrm{a} / 8-\mathrm{b} / 4)
\end{aligned}
$$

$\mathrm{CH}_{4}$

Persamaan tersebut menunjukkan kandungan metana dalam biogas dikorelasikan langsung dengan tahap oksidasi zat organik air limbah. Namun demikian, dalam kenyataannya konsentrasi metana yang teramati jauh lebih tinggi dari perhitungan di atas, hal ini disebabkan karena adanya bagian dari $\mathrm{CO}_{2}$ yang bereaksi pada fase cair. Pada umumnya 8595\% COD keluaran air limbah agro industri dapat terbiodegradasi secara anaerobik, seperti ditunjukkan oleh neraca karbon (gambar 3.3).

Pada gambar 3.3 terlihat bahwa lebih dari $80 \%$ karbon diubah menjadi biogas dan hanya $5-10 \%$ digunakan untuk produksi biomassa. Sintesa biomassa tertinggi terjadi pada air limbah karbohidrat, sedangkan sintesa lebih rendah pada limbah asam lemak dan protein ${ }^{13)}$.

Nilai $\mathrm{pH}$ influen yang berada pada rentang 3,90 hingga 5,02 memang sesuai dengan karkateristik limbah cair tahu yang cenderung bersifat asam. Kandungan asam ini diperoleh dari proses produksi

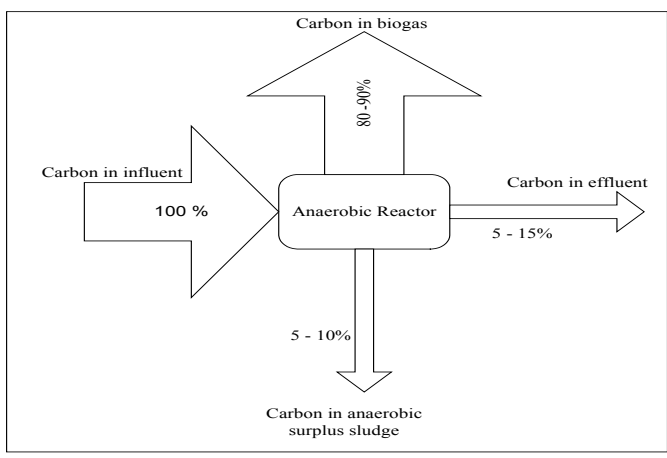

Gambar 3.3.NeracaKarbonUntuk Proses Biometanasi

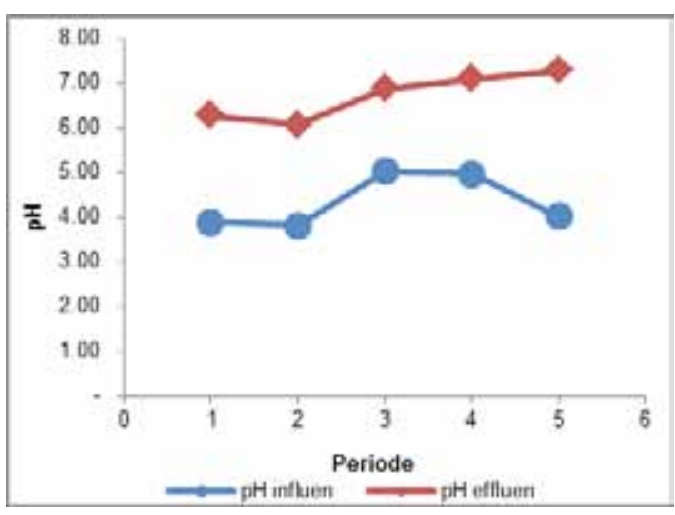

Gambar 3.4. Hasil pengamatan $\mathrm{pH}$ influen dan $\mathrm{pH}$ efluen selama 5 periode

yang melibatkan"pengecutan" dalam tahap penggumpalan atau koagulasi sari tahu menjadi padat. Namun setelah diproses dalam reaktor biogas, kondisi asam justru dapat dikendalikan. Hal ini penting karena pada dasarnya pengendalian $\mathrm{pH}$ dalam reaktor sangat menentukan unjuk kerja reaktor itu sendiri, hal ini disebabkan oleh kompleksitas mekanisme degradasi senyawa organik oleh kemampuan degradasi konsorsium mikroba di dalam reaktor.

Kondisi pH efluen pada setiap periode sangat dipengaruhi oleh kandungan asamasam lemak organik. pH efluen masih dalam kondisi netral yang menunjukkan bahwa reaktor masih berjalan cukup stabil yang menunjukkan asam-asam organik yang terbentuk seperti asam asetat terkonversi menjadi gas metana. Kisaran $\mathrm{pH}$ efluen berkisar antara 6,08-7,28 


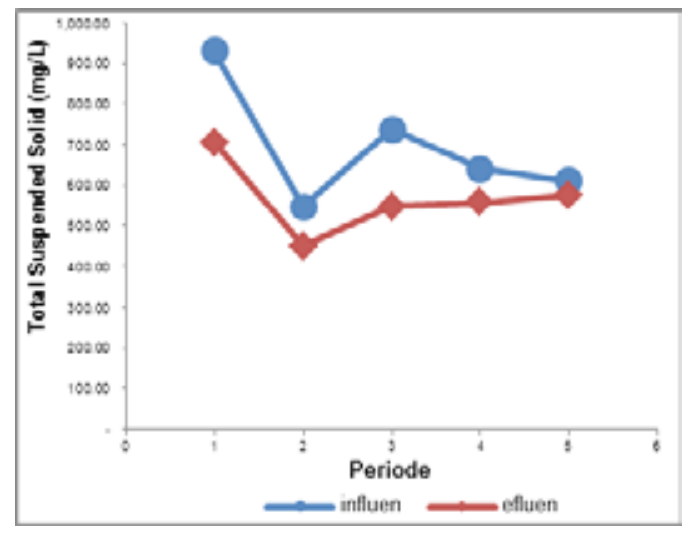

Gambar 3.5. Hasil pengamatan TSS influen dan efluen selama 5 periode

Kondisi padatan tersuspensi (Total Suspended Solid, TSS) pada efluen selama pengamatan berlangsung dan selama pengoperasian berlangsung menunjukan keadaan yang konstan. Hal ini disebabkan pada awal pengoperasian reaktor sebagian total padatan terperangkap pada support material, dan masih tetap melekat dengan baik sampai dengan akhir kriteria desain untuk waktu tinggal 3 hari, hal ini memperlihatkan reaktor cukup stabil dan tidak terjadi wash out atau keluarnya mikroba dari dalam reaktor.

\section{KESIMPULAN}

1. Limbah cair organik dengan konsentrasi yang tinggi, dapat diolah secara biologi menggunakan reaktor anaerobik tipe Fixed bed atau reaktor anaerobik lekat diam.

2. Jenis teknologi ini tidak membutuhkan energi yang tinggi, rendah nutrien dan produksi sludge rendah.

3. Material penyangga mempunyai peranan yang penting dalam unjuk kerja reaktor.

\section{DAFTAR PUSTAKA.}

1. Alia Damayanti, Joni Hermana dan Ali Masduqi, 2004, Analisis Resiko
Lingkungan dari Pengolahan Limbah Pabrik Tahu dengan Kayu Apu, Jurnal Purifikasi, Vol.5, No.4, 2004

2. EMDI-Bapedal, 1994, Limbah Cair Berbagai Industri di Indonesia, Sumber, Pengendalian dan Baku Mutu, EMDIBapedal

3. Anonim. 1995. Peraturan KMNLH : KEP-51/MENKLH/10/1995 tentang baku mutu limbah cair bagi kegiatan industry.

4. Anonim. 2007. Data sekunder monografi desa kalisari, Desa Kalisari, Kabupaten Banyumas, Provinsi Jawa Tengah

5. Benefield, L.D and randall. CW, 1980. Biological Process Desain For Wastewater. Prentice Hall.Inc, Englewood Cliffs.

6. Bitton, Gabriel. 1994. Wastewater Microbiology. Florida: John Wiley and Sons.

7. Rittman, B.E and Mc Carty P.L. 2001. Environmental Biotechnology Principles and Aplication, Boston : Mc Graw Hill.

8. Chavadej, s.1980. Anaerobic Filter for Biogas Production. J. Energy Head Mass Transfer.

9. Indriyati, 2005, Pengolahan Limbah Cair Organik Secara Biologi Menggunakan Reaktor Anaerobik Lekat Diam, Jurnal Air Indonesia, Vol 1, Nomor 3, Tahun 2005

10. Indriyati, 2002, Degradasi bahan organic limbah cair industry permen dengan variasi waktu tinggal, Jurnal Teknologi Lingkungan, Vol 3 No 1, 2002

11. Indriyati, 2003, Proses pembenihan (seeding) dan aklimatisasi pada reaktor 
tipe Fixed Bed, Jurnal Teknologi Lingkungan, Vol 4 No 2, 2003

12. Weiland, P. 1987. Development of Anaerbic Filters for Treatment of high Strength Agro Industrial Waste Water, Bio Process Engineering 2, Springer, Verlag.
13. Weiland, P and K. Wulfret, 1986. Pilot Plant Studies of Different Anaerobic Filter Types for Stilage Treatment, EWPCA Conference on Anaerobic Wastewater Treatment, September, Amsterdam. 